
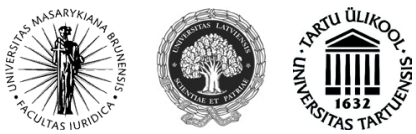

ISSN 1392-6195 (print) ISSN 2029-2058 (online) JURISPRUDENCIJA JURISPRUDENCE 2014, 21(1), p. 259-278.

\title{
KAI KURIOS KRIMINOLOGINĖS PROBLEMOS DVIDEŠIMTMEČIO SOCIALINIŲ POKYČIŲ LIETUVOJE KONTEKSTE
}

\author{
Genovaitè Babachinaitè \\ Mykolo Romerio universiteto Teisès fakulteto \\ Baudžiamosios teisès ir proceso institutas \\ Ateities g. 20, LT-08303 Vilnius, Lietuva \\ Telefonas (+370 5) 2714584 \\ Elektroninis paštas btpi@mruni.eu \\ Artūras Petkus \\ Mykolo Romerio universiteto Teisès fakulteto \\ Baudžiamosios teisès ir proceso institutas \\ Ateities g. 20, LT-08303 Vilnius, Lietuva \\ Telefonas (+370 5) 2714584 \\ Elektroninis paštas apetkus@mruni.eu
}

Pateikta $2014 \mathrm{~m}$. vasario 6 d., parengta spausdinti $2014 \mathrm{~m}$. kovo $13 \mathrm{~d}$.

doi:10.13165/JUR-14-21-1-13

\section{Ivadas}

Lietuvos Respublikos Vyriausybè 2012 m. lapkričio 14 d. nutarimu Nr. 1381 patvirtino Nacionalinès nusikaltimų prevencijos ir kontrolès programos igyvendinimo tarpinstitucinị veiklos planą ${ }^{1}$, kuriame vienu iš veiklos prioritetų išskyre் „,_..>

1 Lietuvos Respublikos Vyriausybės 2012 m. lapkričio 14 d. nutarimas Nr. 1381 „Dèl Naciona-

Jurisprudencija/Jurisprudence

(C) Mykolo Romerio universitetas, 2014

(C) Mykolas Romeris University, 2014
ISSN 1392-6195 (print), ISSN 2029-2058 (online) http://www.mruni.eu/lt/mokslo_darbai/jurisprudencija/ http://www.mruni.eu/en/mokslo_darbai/jurisprudencija/ 
nusikalstamumo prevencijos sistemos tobulinimas per mokslinius tyrimus; nusikalstamumo prevencijos subjektų mokymas; nacionalinio ir tarptautinio bendradarbiavimo nusikalstamumo prevencijos srityje plètra; nuteistųjų neteisèto elgesio prevencijos ir kontrolès laisvès atėmimo vietose sistemos tobulinimas“. Tai svarbus iššūkis tiek mokslininkams, tiriantiems nusikalstamumą ir su juo susijusius socialinius procesus, tiek ir praktikams, kurie, esant ribotiems finansiniams bei žmogiškiesiems ištekliams, siekia užtikrinti vidaus saugumą valstybejje.

Neatsitiktinai šiame straipsnyje nusikalstamumo kontekstas nagrinèjamas ịvairiais pjūviais. Istoriné apžvalga, statistinių duomenų analizé, asmenybės charakteristika ir kriminogeninių procesų ižvalgos yra pateikiamos siekiant sudaryti prielaidas tolesniems tarpdisciplininiams tyrimams. Minètoje programoje nurodyti siekiniai: \#<..> pagerinti nusikalstamumo prevencijos sistemos valdymą ir efektyvumo įvertinimą; išlaikyti pusiausvyrą tarp nusikaltimų prevencijos priemonių ir nusikaltimų tyrimo bei atsakomybès neišvengiamumo principo igyvendinimo “2 ipareigoja visus nusikalstamumo prevencijoje veikiančius subjektus suvokti sisteminio požiūrio būtinybę.

Straipsnyje akcentuojama, kad atkūrus Lietuvos nepriklausomybę prasidèjo demokratinès valstybès ir visuomenès kūrimo procesas; atsirado būtinybè neatidèliotinai spręsti daugelị teorinių ir praktinių teisès srities, taigi ir kriminologinių, problemų. Juolab kad socialiniai pokyčiai veikia ir nusikalstamumo kitimą bei nusikaltimų prevencijos institutų ir jų veikimo būdų demokratèjimą. Per pastarąji penkmetị taip pat vyko sudètingi neprognozuoti socialinès politinès aplinkos pokyčiai, kurių atoveiksmis nusikalstamumui jau matomas šiandien. Tai sudaro prielaidas ịvertinti esamą kriminogeninių procesų būklę ir ieškoti tyrimo krypčių ateičiai.

Ivertinus kriminologijos mokslo įdirbị atskirose nusikalstamumo kontrolès ir prevencijos tyrimo srityse bei praktinę teisėsaugos ir kitų nusikalstamumo prevencijos srityje dirbančių institucijų patirț, tyrimo tikslas yra išskirti kriminologiškai svarbius elementus bei veiksnius, kurių tolesnis mokslinis tyrimas padètų didinti nusikalstamumo prevencijos veiksmingumą.

Tyrimo objektas yra nusikalstamumas, atskiros jo rūšys, nusikaltimo aukos bei nusikaltèlio asmenybès bruožai.

Tyrimo metu taikyti registruoto nusikalstamumo statistinès analizès, apibendrinimo, lyginamasis, nagrinèjant registruoto nusikalstamumo dinamiką ir valstybès institucijų reakciją $\mathfrak{x}$ ji - istorinis, analizuojant mokslinę literatūrą - sisteminés analizès metodai.

linès nusikaltimų prevencijos ir kontrolès programos igyvendinimo tarpinstitucinio veiklos plano patvirtinimo“. Valstybès žinios. 2012, Nr. 135-6897.

2 Lietuvos Respublikos Vyriausybès 2012 m. lapkričio 14 d. nutarimas Nr. 1381 „Dèl Nacionalinès nusikaltimų prevencijos ir kontrolès programos igyvendinimo tarpinstitucinio veiklos plano patvirtinimo“, supra note 1. 


\section{1. Šiuolaikinio nusikalstamumo prevencijos problematika}

Atkūrus Lietuvoje nepriklausomybę tiek akademinès bendruomenès, tiek teisėsaugos institucijų atstovai, tiek ir politikai daug diskutavo dẻl baudžiamosios politikos vystymosi perspektyvų, dèl nusikalstamumo kontrolès ir prevencijos siekinių. Tuo metu buvo aktualu aptarti vieną iš problemiškiausių baudžiamosios politikos elementų - mirties bausmès panaikinimą. Nesigilindami ị, be jokios abejonès, svarbius kitų mokslo sričių argumentus šiuo klausimu, paminėsime kriminologiškai svarbiausius motyvus. 1997 m. „Vilmorus“ atliktas viešosios nuomonès tyrimas parodè, kad dauguma respondentų (beveik trys ketvirtadaliai) nepritartų mirties bausmès panaikinimui ${ }^{3}$. O pvz., Skandinavijos šalys mirties bausmės atsisakè labai seniai ${ }^{4}$, ir dèl to neiškilo, nepadaugèjo nusikaltimų prevencijos problemų. Lietuvos visuomenė turejo perimti socialinių santykių pažangą ir kartu išsaugoti nacionalinio charakterio ir dvasios ypatumus esminių demokratinių pokyčių raidoje. Argumentuotai teigta, kad viešoji nuomonè nèra tolygi tautos valiai; ir kad viešosios nuomonès tyrimu negalima ieškoti atsakymo dèl sudètingų socialinių klausimų sprendimo būdų. Šią nuostatą galima pagrịsti Lietuvoje registruotų nužudymų statistinių duomenų dinamikos analize (1 pav.).

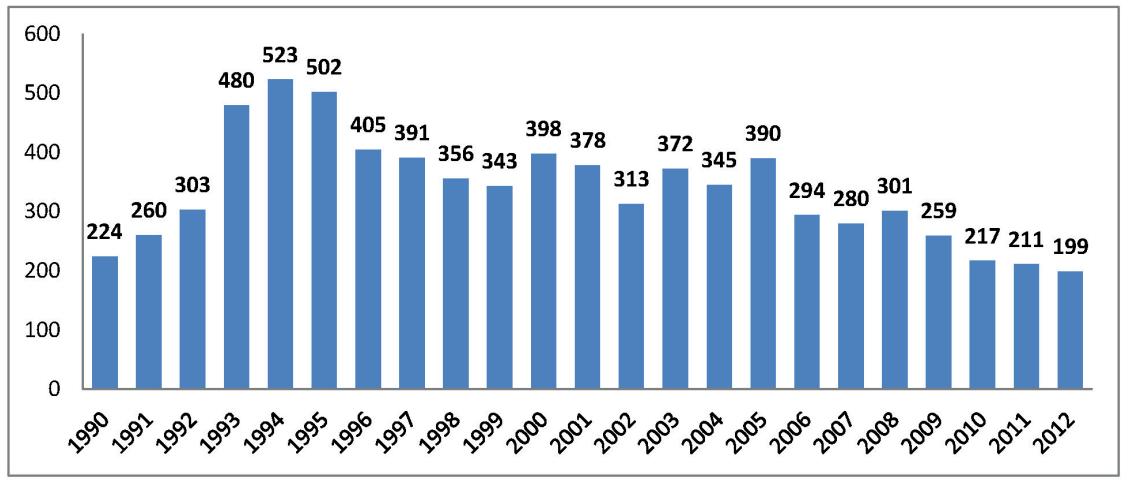

1 pav. Nužudymai (su pasikèsinimais) (BK 129-131 str. $)^{5}$

3 Plačiau žr.: Babachinaitè, G. Viešoji nuomonė ir mirties bausmė: prevencijos strategija. Jurisprudencija. 1998, 10(2).

$4 \quad$ Ibid.

5 Tyčiniai nužudymai (su pasikèsinimais). [interaktyvus]. [žiūrèta 2013-08-29]. <http://www. nplc.lt/sena/stat/nus/nus11.htm>; Duomenys apie nusikalstamumą Lietuvos Respublikoje. Užregistruotos ir ištirtos nusikalstamos veikos (Forma 1 Ž). Informatikos ir ryšių departamentas prie Vidaus reikalų ministerijos. [interaktyvus]. [žiūrèta 2013-08-29]. <http://www.nplc. lt:8000/asis/>. 
Mirties bausmé Lietuvoje galiojo iki 1998 metų $^{6}$. Tačiau būtent po mirties bausmès panaikinimo per pastaruosius 15 metų matoma bendra registruotų nužudymų skaičiaus mažèjimo tendencija. Tai reiškia, kad mirties bausmè pati savaime nedaro lemiamos įtakos nužudymų skaičiaus mažejimui (netgi priešingai - jos galiojimo laikotarpiu nužudymų skaičius buvo padidejęs daugiau nei 2 kartus), tad neturètų būti laikoma tiek svarbia, nuo nužudymų asmenis atgrasančia prevencijos priemone. Tai tik vienas iš pavyzdžių, parodantis, kad nusikalstamumo problemų sprendimas gali būti klaidingas, jei esama kriminogeninè būklè vertinama neprofesionaliai.

Vykstant demokratinès teisinès valstybès ir visuomenès kūrimosi procesui išryškejo trys nusikaltimų prevencijos problemų grupés: 1) bausmių politikos ir jų skyrimo praktikos tobulinimas; 2) laisvès atėmimo ịstaigų darbo kokybès gerinimas; 3 ) pagalba asmenims, grižusiems iš laisvės atėmimo ịstaigų. Visuomenè palaiko ir netgi reikalauja aktyvesnių demokratinių poslinkių tvarkant daugelį socialinio ir ekonominio gyvenimo sričių, tačiau vienintele priemone ir nusikalstamumo mažinimo garantu laiko bausmių griežtinimą bei nusikaltimus padariusių asmenų laisvès ir daugelio kitų teisių apribojimą. Politinès partijos, tiek valdančiosios, tiek opozicinès, siekdamos populiarumo visuomeneje, nedrịsta pareikšti kitokios mokslo duomenimis paremtos nuomonès (2000 m. padètis). Tuo tarpu mokslininkai kriminologai ne vien tik Lietuvoje, bet ir kitose šalyse pateikia akivaizdžius tokio mąstymo nenaudingumo ir nepagrịstumo įrodymus". „Šiuolaikineje Lietuvos teisès doktrinoje pripažįstama, kad baudžiamoji atsakomybe yra kraštutiné priemonè (ultima ratio) ginant visuomenę nuo ịvairių teisinès tvarkos pažeidimų. Tačiau nèra aiškumo dèl šios racionalumu ir kriminologiniais tyrimais pagristos idejos teisinio statuso ir privalomumo kuriant ir taikant baudžiamuosius įstatymus. “8 Pažymètina, kad trūkstant sisteminio požiūrio ị nusikalstamumo prevenciją, su ja susijusị teisèkūros procesą bei teisés taikymo praktikoje kylančias problemas, valstybès institucijų pareigūnai, nuo kurių sprendimų priklauso baudžiamosios politikos nuoseklumas Lietuvoje, kaip pagrindinę adekvačią reakciją i nusikalstamumą pripažịsta valstybinès prievartos priemonių taikymą. Tai ydinga praktika, kurios rezultatu tampa perpildytos pataisos ịstaigos, o šios prievartos vykdymo rezultatai ima netenkinti visuomenès lūkesčių.

Laisvès atėmimo ịstaigų darbo sèkmè pirmiausiai priklausytų nuo bausmių politikos pažangumo ir jų skyrimo praktikos. Konkreti šios politikos išraiška būtų tai,

61996 m. mirties bausmès vykdymas buvo sustabdytas, o 1998 m. gruodžio 21 d. Lietuvos Respublikos Seimas mirties bausmę panaikino; Lietuvos Respublikos baudžiamojo kodekso $22,24,42,43,49,50,54^{(1)}, 71,75,105,227^{(1)}, 227^{(3)}$ straipsnių pakeitimo ịstatymas. Valstybès žinios. 1998, Nr. 115-3238.

7 Žr.: Christie, N. Crime control as Industry. London, New York, 1993; Gavenaité, A. Bausmès samprata ir funkcijos pozityvistineje ir kritineje kriminologijos tradicijose. Daktaro disertacija. Socialiniai mokslai, sociologija. Vilnius: Vilniaus universitetas, 2008, p. 115-147.

8 Fedosiuk, O. Baudžiamoji atsakomybẻ kaip kraštutinè priemonė (ultima ratio): teorija ir realybè. Jurisprudencija. 2012, 19(2): 715. 
kad laisvès atėmimo bausmès būtų optimalios, t. y. nuteistasis laisvès atėmimo vietoje nebūtų ilgiau nei reikia. Savo ruožtu institucijų, sprendžiančių grịžusių iš laisvès atėmimo îstaigų asmenų problemas, prevencinio darbo veiksmingumas yra tiesiogiai susijęs su laisvès atėmimo ịstaigų darbo kokybe. Vienu iš laisvès apribojimo bausmès optimalumo kriterijų turètų tapti ir nuteistojo asmenybės kriminalizavimo procesas, t. y. kriminogeninių elementų (nuostatų, vertybių, iguudžių) susiformavimo rizika asmenybės lygmenyje, nuteistajam atliekant laisvès atėmimo bausmę. Iki šiol tai mažai tyrinèta sritis. Viešoje erdveje egzistuoja nuostata, kad pataisos įstaigos - tai „nusikaltèlių universitetai“, tačiau giluminių tyrimų Lietuvoje kol kas stinga, kad pagal aiškius kriterijus būtų galima ịvertinti nuteistojo laisvės atėmimo bausme asmenybės pokyčius, kurie vèliau nusikalstamos veikos mechanizme veikia kartu su socialiniais nusikalstamo elgesio determinantais.

Pažangesnis (ir kartu veiksmingesnis) minètų dviejų grupių problemų sprendimas - pagrindinè prielaida trečiosios grupès prevencinių problemų sẻkmingam sprendimui. Socialiniai darbuotojai, teikiantys pagalbą grįzusiems iš pataisos ịstaigų, susidurtų su mažiau desocializuotais asmenimis, kuriems būtų lengviau prisitaikyti visuomenèje. Taigi socialinių darbuotojų teikiama pagalba būtų žymiai veiksmingesnè ir kainuotų mažiau. Be abejo, pagalbos priemonès asmenims, grịžusiems iš laisvès atėmimo ịstaigų, yra daug kainuojantis dalykas. Valstybès skiriamos lešos šiai problemai spręsti lemia, kaip ir koks darbas bus atliekamas. Svarbu taupiai ir veiksmingai naudoti skirtas lèšas. Nemažą indèlị i ṣ̨̌ darbą ịnešè ir ịvairios nevyriausybinès organizacijos, veikiančios Lietuvoje ir nebūtinai remiamos valstybès.

Kriminologinių problemų nagrinejjimas ir jų sprendimo būdų paieška - visuomet aktualus dalykas, nesvarbu, kokia yra nusikalstamumo tendencijų raida, t. y. nusikalstamumas didèja ar mažeja. Neteisinga manyti, kad jeigu registruotas nusikalstamumas nedidètų, tai kriminologinè problematika, tarkime, nusikalstamumo prevencijos problema, nebūtų svarbi. Tik nuosekliai nagrinejjant ir sprendžiant kriminologines problemas tikètina, kad efektyviau bus sprendžiamos nusikalstamumo prevencijos problemos. Taigi kriminologinè problema yra permanentiškai aktuali, gali keistis tik aktualumo kryptingumas, t. y. gali būti išskiriami tam tikri jo akcentai.

Šiuolaikinei nusikalstamumo prevencijos problemos sprendimo versijai, vyraujančiai visuomenèje, būdinga nuomonè, kad nusikalstamumo prevencija yra pirmiausia teisėsaugos institucijų pareiga. Taip pat manoma, kad tik teisėsaugos institucijų veiksmingas ir tinkamai organizuotas darbas iš esmès užtikrina nusikalstamumo prevencijos sẻkmę šalyje. Ši nuomonè, nors ir plačiai paplitusi bei žiniasklaidos eskaluojama, kriminologiniu požiūriu atrodo klaidinga. Teisėsaugos institucijos Lietuvoje iš esmès atlieka prievartinès nusikalstamumo prevencijos darbą ir atsako už šio darbo kokybę. Taigi prievartinè nusikalstamumo prevencija iš esmès yra specialioji nusikalstamumo prevencija valstybiniu, socialiniu, skirtingų šalies regionų ir socialinių grupių lygiu, bet svarbiausia - poveikio konkretiems asmenims, t. y. individualiosios specialiosios prevencijos lygiu. Represinès prievartinès prevencijos vyravimą 
ir jo padarinius Lietuva paveldejo iš sovietmečio. Atgavus nepriklausomybę ir staigiai didèjant registruotam nusikalstamumui Lietuvoje ši sovietinès kilmès represinè prevenciné politika buvo tęsiama dar dešimtmetį dabar jau demokratinę visuomenę kuriančios valstybès. Toliau daugejo piliečių, nuteistų kalèti laisvès atėmimo ir kitose laisvès apribojimo įstaigose. Per pirmąji nepriklausomybės dešimtmetị absoliutus nuteistųjų skaičius padidèjo 2,5 karto. Nuteistųjų skaičiaus didejjimas 0,5 karto lenkè užregistruotų nusikaltimus padariusių asmenų skaičiaus didèjimą. 2003 m., baudžiamajai politikai tampant progresyvesne po naujų Baudžiamojo kodekso, Baudžiamojo proceso kodekso, Bausmių vykdymo kodekso ịsigaliojimo, Lietuvos pataisos įstaigose laikomų asmenų skaičius nuo 11070 - 2003 m. pradžioje sumažèjo iki 7866 - 2008 m. pradžioje ir keletui metų stabilizavosi9. Tačiau nuo $2008 \mathrm{~m}$. stebimas nuoseklus Lietuvos pataisos ịstaigose esančių asmenų skaičiaus didèjimas ir 2012 m. tokių asmenų buvo vidutiniškai $9906^{10}$. Vertinant susidariusią situaciją, galima daryti prielaidas, kad tokius pokyčius kartu lemia socialinès problemos, kurias sukèlė Lietuvoje ir visame pasaulyje susiformavę ekonominiai iššǔkiai bei įstatymų leidžiamosios valdžios reakcija ị viešumoje plačiai aptariamus nusikaltimus, kuri praktikoje pasireiškia teikiant įstatymų projektus dèl Baudžiamajame kodekse numatytų sankcijų didinimo. Kaip jau buvo minèta, represinio pobūdžio reakcija ị nusikalstamumą nèra adekvati priemonè, nes nusikalstamumo didejimą lemia ne baudžiamųjų sankcijų „efekto" sumažejimas, o socialiniai, ekonominiai ir kiti veiksniai, todèl ir prevencija turi būti orientuota būtent ị šiuos kriminogeninius veiksnius.

Tačiau prievartinè nusikalstamumo prevencija yra santykinai nedidele nusikalstamumo prevencijos apskritai dalis. Todèl kriminologiškai ir apskritai socialiai nepagrịsta užkrauti visą atsakomybę už nusikalstamumo prevencijos kokybę ir šios prevencijos mastą teisèsaugos institucijoms. Juo labiau kad pažangiose demokratinèse šalyse, ypač Skandinavijos, prievartinę nusikalstamumo prevenciją ir apskritai baudžiamąją justiciją yra ištikusi krize ${ }^{11}$.

Prievartinès nusikalstamumo prevencijos procese socialinis konfliktas lieka neišspręstas, o tik atidedama tolesnè jo raiška. Teisèsaugos institucijų veikla dažniausiai nukreipta ị nusikaltimų ir kitų teisès pažeidimų padarinių užkardymą, o ne į priežasčių, kurios šiuos padarinius sukūrè, šalinimą. Šios krypties nusikaltimų prevencija kitaip dar vadinama reaktyviąja prevencija. Visuomenès ir valstybės pastangos veikti nusikalstamumo priežastingumą sudaro vadinamąją proaktyviąją prevenciją. Visos šalies visuomenès, atskirų jos narių, piliečių susivienijimų (darinių) veikla, ịvairių

9 Kalejimų departamentas prie Teisingumo ministerijos. Asmenų, laikomų KD įstaigose, skaičius metų pradžioje [interaktyvus]. [žiūrèta 2013-09-10]. <http://www.nplc.lt:8000/asis/>.

10 Kalejimų departamento prie Lietuvos Respublikos teisingumo ministerijos 2012 metų veiklos ataskaita. 2013, Nr. 1S-440 [interaktyvus]. [žiūrèta 2013-09-23]. <http://www.kalejimudepartamentas.lt/lt/kalejimu-departamentas/veikla/ataskaitos/metines.html>.

11 Žr.: Chistie, N. Limits to pain. Oxford, Martin Robertson, 1992. 
valstybės institucijų veikla siekiant efektyviai spręsti socialines problemas ir sudaro veiksmingiausią proaktyviąją nusikaltimų prevenciją. Savo ruožtu nusikalstamumo prevencija apskritai (tiek prievartinè, tiek ir proaktyvioji) yra valstybės socialinès politikos plačiąja jos prasme dalis. Proaktyviosios (arba bendrasocialinès) nusikalstamumo prevencijos subjektai šị darbą atlieka vykdydami ịprastines savo funkcijas, t. y. dirbdami ịprastą jų kompetencijai priskirtą darbą. Šiuo darbu (jeigu jis tinkamai atliekamas) jie mažina nusikaltimų užkardymo darbo mastą ir taip palengvina teisésaugos institucijoms atlikti reaktyviąją prevenciją, daro ją efektyvesnę. Taigi socialinejje erdvejje problemos yra susiję tarpusavyje, veikia viena kitos paplitimą, apimtis ir, pagaliau, sprendimą.

\section{Registruoto nusikalstamumo pokyčių ir socialinių bei politinių pokyčių sąveika}

Kriminologijoje daugiausia demesio nuolat buvo skiriama statistiniams nusikalstamumo pokyčiams nagrinèti, nes yra nuolat aktualu nustatyti realią nusikalstamumo raidą Lietuvoje lyginant su kitų ES šalių atitinkama padètimi bei tirti, kaip socialiniai pokyčiai veikia nusikalstamumo raidą. Istorinis reakcijos ị nusikalstamumą aspektas tampa aktualus dèl galimybès kompleksiškai vertinti nusikalstamumo priežastingumą bei modeliuoti galimas nusikalstamumo prevencijos priemones, priklausomai nuo socialinių pokyčių valstybejje.

Nusikalstamumo raida Lietuvoje buvo nagrinėjama nuo Lietuvos valstybės atkūrimo $1918 \mathrm{~m}$. Tuo metu Lietuva iš esmès buvo kaimiškas kraštas - XX a. pradžioje Lietuvos kaimuose gyveno apie 90 proc. visų valstybès gyventojų; vèliau, $1941 \mathrm{~m}$., Lietuvos kaime gyveno 78 proc. visų valstybės gyventojų ${ }^{12}$.

1918-1940 m. Lietuvos kaimo gyventojų nusikalstamumas iš esmès lèmé nusikalstamumo lygị visoje valstybeje; ir pagal daromas nusikalstamas veikas, kurios tuo metu vyravo, tai buvo kaimiško tipo nusikalstamumas. Prieškarinio nusikalstamumo raidą Lietuvoje santykinai galima suskirstyti ị du laikotarpius: $1918-1928 \mathrm{~m}$. ir 1929-1939 m. Iki $1929 \mathrm{~m}$. buvo kuriamos, tobulinamos ir reorganizuojamos valstybinès valdžios ir kitos valstybès institucijos, teisėsaugos sistema. 1919 m. priimti Laikinosios Konstitucijos pamatiniai dèsniai, o 1922 m. ir 1928 m. priimtos Konstitucijos, išleidžiami kiti nepriklausomai valstybei svarbūs ịstatymai; iš dalies pakeičiamas galiojantis Lietuvoje carinès Rusijos baudžiamasis statutas. Tačiau nusikalstamumo tendencijų Lietuvoje šiuo laikotarpiu tyrinèti beveik neįmanoma dèl daugelio priežasčių. Pirma, dèl didelio nusikalstamų veikų latentiškumo. Antra, dèl Lietuvos teritorinès apimties kitimo. Trečia, dèl nusikaltimų registravimo pagrindų kaitos skirtumų ir tarpusavio nesuderinamumo (pvz., su Klaipėdos krašto nusikalstamumo statistika). Ketvirta, radikaliai kito gyventojų skaičius. Penkta, buvo daug amnestijų. 
Šešta, didelè migracija ị (iš) užsienio šalis (1919-1921 m. daug piliečių išvyksta ị užsienį ir apie 20 proc. jų kasmet grižta $)^{13}$.

Antrasis laikotarpis, po 1930 m., pasižymi santykinai gerai sutvarkyta statistine nusikalstamumo registracija. Tačiau ir šiuo laikotarpiu $(1933 \mathrm{~m}$.) priimtas Teismų santvarkos įstatymas labai pakeitė nusikalstamumo registravimo pagrindus. Ypač smarkiai pasikeitė nusikalstamumo registravimo pagrindai 1939 m. (pvz., $1939 \mathrm{~m}$. užregistruotų nusikaltimų skaičius, palyginti su 1938 m., sumažèjo 3,2 karto). Kita vertus, pagal tuometinę baudžiamųjų ịstatymų tradiciją baudžiamųjų veikų ribos buvo gerokai platesnès, santykinai apèmè ir dabartinius administracinius teisès pažeidimus.

Apskritai nusikalstamumas Lietuvoje tuo metu buvo panašus ị daugelio Europos valstybių nusikalstamumo raišką, tačiau turèjo ir ypatumų: Lietuvoje nusikalstamumas nebuvo sunkaus, organizuoto pobūdžio; nusikaltimai pagal padarymo vietą ir motyvus buvo paprastesni, nesudètingi, nesunkūs; pagal padarymo būdą dažniausiai buvo „nežiaurūs“, sudètingos techninès priemonès nusikaltimams daryti buvo naudojamos retai. Šie požymiai, kaip jau buvo minèta, būdingesni kaimiškojo tipo nusikalstamumui (tarkime, kaip ir Skandinavijos šalyse tuo metu), o ne urbanizuotos visuomenès nusikalstamumui. Tai liudija ir gana didelis jo išaiškinamumas (pvz., $1938 \mathrm{~m}$. bendras nusikaltimų išaiškinamumo vidurkis buvo apie 90 proc.).

Kompleksiškai vertinant 1918-1940 m. registruotą nusikalstamumą - jo padidèjimas per šį laikotarpị neturètų viršyti vieno penktadalio (apie 20 proc.).

Sẻkmingą nepriklausomos Lietuvos valstybès ir visuomenès raidą nutraukẻ sovietų okupacija $1940 \mathrm{~m}$. ir vèliau prasidèjęs Antrasis pasaulinis karas, pokarinis pasipriešinimo okupacijai laikotarpis, prievartinė kolektyvizacija. Galima sakyti, kad socialistinè santvarka Lietuvoje įsigaliojo po $1960 \mathrm{~m}$. - prasidejjo stabilus jos laikotarpis.

Taigi 1961-1987 m., vadinamojo brandaus socializmo laikotarpiu, registruotu nusikaltimų Lietuvoje padaugèjo nuo 11708 iki 20 037, t. y. beveik dvigubai ${ }^{14}$.

Nuo 1988-1989 m. nusikalstamumas ima kisti dèl M. Gorbačiovo „perestroikos“ visuomeneje ir ekonomikoje. Nors ši „perestroika“ pradèta anksčiau, tačiau nusikalstamumo pokyčių Lietuvoje atsirado būtent 1989 m., nes nusikalstamumas šiek tiek vèluoja reaguodamas ị ịvairius socialinius procesus.

M. Gorbačiovo laikais susikūręs organizuotas nusikalstamumas Lietuvoje jau turejo gana stiprias struktūras prieš atkuriant mūsų nepriklausomybę.

Apskritai nusikalstamumo Lietuvoje etapas, prasidèjęs 1988-1989 m., tęsėsi ir atkūrus nepriklausomybę, maždaug iki 1995-1996 m. Per ši trumpą aštuonerių metų laikotarpi registruotas nusikalstamumas Lietuvoje padidejjo maždaug tris kartus. Nepilnamečių nusikalstamumo rodikliai dar radikaliau kito. Per pirmuosius vienuolika

13 Žr.: Babachinaité, G. Kriminologiniai nusikalstamumo raidos Lietuvoje periodizacijos aspektai. Lietuvos teisés tradicijos: mokslinės konferencijos medžiaga. Vilnius: Justitia, 1997.

Ibid. 
nepriklausomybės metų nepilnamečiai per metus vidutiniškai padarydavo po 21 tyčinị nužudymą (4 kartus daugiau negu per ankstesnị laikotarpị); 14 tyčinių sunkių sveikatos sužalojimų (dabar - sunkių sveikatos sutrikdymų) (1,5 karto daugiau negu per ankstesnį laikotarpi)); išžaginimų ir pasikèsinimų išžaginti per metus vidutiniškai būdavo užregistruojama po 26 , t. y. maždaug tiek pat arba net ir mažiau negu vidutiniškai per ankstesnị laikotarpị. Taigi galima konstatuoti, kad po $1995 \mathrm{~m}$. Lietuvoje, kai bendras užregistruotas nusikalstamumas stabilizavosi, nepilnamečių padarytų ir užregistruotų smurtinių nusikaltimų ne mažèjo, o daugèjo, ypač tyčinių nužudymų ir tyčinių sunkių kūno sužalojimų (sunkių sveikatos sutrikdymų).

Remiantis registruoto nusikalstamumo koeficientais (10 tūkst. gyv.) kaimo gyventojų kriminalinis aktyvumas po nepriklausomybès atkūrimo iki 1994-1995 m. smarkiai augo, susilygino su miesto gyventojų kriminaliniu aktyvumu, 1993 m., kai prasidejo staigi socialistinių ūkio ir kultūros struktūrų griūtis, netgi viršijo jị.

Šiuolaikiniam registruotam nusikalstamumui Lietuvoje būdinga tai, kad jis po 1995-1996 m. atitinka bendrą Europos Sąjungos tendenciją - nedidelis kasmetinis padidèjimas. Ši tendencija Lietuvoje buvo iki 2004 m., o vèliau bendras registruotas nusikalstamų veikų skaičius nedaug mažèjo ir, pvz., $2011 \mathrm{~m}$. buvo 15 proc. sumažėjęs, lyginant su $2004 \mathrm{~m}$. Nusikaltimų lygis mieste maždaug 1,6 karto viršijo nusikaltimų lygị kaime, o baudžiamųjų nusižengimų lygis mieste maždaug 1,7 karto viršijo baudžiamųjų nusižengimų lygị kaime.

Šiuolaikiniam nusikalstamumui Lietuvoje būdingas tolesnis sunkiausių smurtinių nusikaltimų registruoto skaičiaus mažèjimas: nužudymų skaičius per laikotarpi nuo 2004 m. sumažèjo 39 proc.; sunkių sveikatos sutrikdymų - 56 proc.; ǐ̌žaginimų ir pasikèsinimų - 26,5 proc.; plèšimų - 53 proc.; transporto priemonių vagysčiu - 65 proc., automobilių vagysčiu -74 proc.; vagysčių iš gyvenamųjų patalpų - 55,5 proc.; viešosios tvarkos pažeidimų - maždaug 13 proc.

Tačiau nusikaltimų, susijusių su disponavimu narkotinėmis medžiagomis, kontrabandos nusikaltimų užregistruotas skaičius daugiau kaip du kartus padidejjo. Turto sunaikinimo ar sugadinimo bei sukčiavimų raida Lietuvoje vis labiau panašèja ị išsivysčiusios rinkos ekonomikos šalių nusikalstamumo raidą. Turto sunaikinimo ar sugadinimo registruotas skaičius per pastaruosius dešimt metų padidèjo beveik 80 proc., o sukčiavimų - beveik 92 proc. Tačiau Lietuvoje minètų nusikalstamų veikų lygis 100000 gyv. vis vien yra 2-3 kartus mažesnis negu, tarkim, Skandinavijos šalių ${ }^{15}$.

\section{Viktimologinis nusikalstamumo Lietuvoje aspektas}

Po baudžiamųjų ịstatymų reformos Lietuvoje nuo $2004 \mathrm{~m}$. atsirado patikimi valstybiniai statistiniai duomenys apie kriminalinès viktimizacijos procesų aukas.

15 Plačiau žr.: Babachinaite, G. Šiuolaikinio registruoto nusikalstamumo Lietuvoje pagrindiniai bruožai. Jurisprudencija. 2012, 19(4). 
Didžiausia registruotų nukentėjusių asmenų dalis (apie 95 proc.) nukentèjo nuo nusikaltimų; likusieji 5 proc. - nuo baudžiamųjų nusižengimų. Pasiskirstymas pagal lytị atrodo vidutiniškai taip: 61 proc. - vyrai ir 39 proc. - moterys. Vienas ketvirtadalis registruotų asmenų nukentejo kaimo vietovėse, o trys ketvirtadaliai - miestuose. Suaugusieji sudaro maždaug 91 proc. visų užregistruotų asmenų, nukentėjusių nuo nusikalstamų veikų. Tačiau bendrame registruotų nukentèjusiųjų skaičiuje vaikų dalis yra labai nepastovi, smarkiai kintanti kasmet. Šitokia padètis kriminologiniuose tyrimuose pastaruosius keturiasdešimt metų aksiomatiškai laikoma voliuntaristiniu duomenų registravimo reguliavimu, taigi realus nukentejjusiųjų nuo nusikalstamų veikų vaikų skaičius yra labiau latentiškas negu suaugusiųjų analogiškas skaičius. Didžiausias nukentejjusiųjų skaičius yra jauno amžiaus (iki 30 metų) asmenys. 30-39 m. amžiaus asmenys nukenčia panašiai kaip ir 25-29 m. amžiaus asmenys, o po $40 \mathrm{~m}$. amžiaus aukų skaičius gana ženkliai mažeja, ir 60-79 m. žmonès nukenčia 2 kartus rečiau negu 40-59 m. amžiaus asmenys. Tarp nepilnamečių $2004 \mathrm{~m}$. vieną trečdalị sudarè asmenys iki $14 \mathrm{~m}$. amžiaus, likusius 2/3 - 14-17 m. Tačiau dabar stebima labai nepalanki tendencija, kad asmenų iki $14 \mathrm{~m}$. amžiaus dalis nuolat didejja ir artèja prie 50 proc. ${ }^{16}$ Daugeja kūdikių, ikimokyklinio amžiaus ir vaikų iki 13 metų skaičius tarp registuotų nukentejjusiųjų nuo nusikalstamų veikų Lietuvoje.

Iki šių dienų išlieka aktualus kriminologinemis žiniomis paremtas požiūris ị teisèsaugos institucijų bei teisminès valdžios darbo specifiką ir su tuo susijusius iššūkius. Pastaruoju metu daug diskutuojama apie visuomenès pasitikejjimą prokuratūra, teismais, galimas korupcijos apraiškas šiose institucijose ${ }^{17}$. Tačiau tuo pat metu būtina suvokti, kad vis dar egzistuoja viktimizacijos grèsmè minėtų institucijų darbuotojams. 2000 m. Lietuvoje ir Suomijoje buvo atliktas viktimologinis neteisètų bandymų paveikti teisèjų ir prokurorų darbą Lietuvoje tyrimas. Tyrimo duomenys parodè, kad kas aštuntas teisejjas patyrè dvejopą labiausiai paplitusį neteisètą poveiki - grasinimus ir bandymus papirkti. Kas septintas prokuroras patyrė grasinimus. Tačiau apskritai nuo neteisètų bandymų paveikti teisejjų ir prokurorų darbą nukentèjo nuo 5,4 proc. iki 16,6 proc. teisejjų ir nuo 3,9 proc. iki 15,6 proc. apklaustųjų prokurorų (pagal atskiras neteisèto poveikio rūšis).

Dar viena problema, aptarta viktimologų publikacijose, - tai saugumo jausmo ir nusikaltimų baimès raida Lietuvoje. Reikalas tas, kad nusikaltimų baimès lygis Lietuvoje yra maždaug du kartus didesnis negu ES šalių analogiškas vidurkis, nors kriminalinè viktimizacija Lietuvoje atitinka ES šalių vidurkį ${ }^{18}$. Vykstant spartiems so-

16 Plačiau žr.: Babachinaitė, G. Kriminalinès viktimizacijos Lietuvoje pagrindinių statistinių rodiklių kriminologinè analizè. Jurisprudencija. 2011, 18(3).

17 Vileikienè, E. Lietuvos gyventojų požiūris j̣ teismus [interaktyvus]. [žiūrèta 2014-03-07]. <http:// www.teismai.lt/dokumentai/gyventoju\%20apklausa\%20\%28teismai\%29\%202013.pdf> .

18 Plačiau žr.: Babachinaitè, G. Saugumo jausmo ir nusikaltimų baimės raida Lietuvoje. Jurisprudencija. 2006, 1(79). 
cialiniams pokyčiams, tampa aktualu naujai tyrinèti visuomenės saugumo suvokimą ir prielaidas. Nesaugiai aplinkoje besijaučiantys asmenys yra priversti neracionaliai skirstyti išteklius savo poreikiams (tarp jų - ir saugumo) patenkinti, didejja emocinis diskomfortas visuomenèje, mūsų anksčiau jau minètas nepasitikèjimas teisèsaugos institucijomis. Ilgainiui tokia situacija sudaro prielaidas nusikalstamumo savikūros vystymuisi, registruoto nusikalstamumo didejimui.

\section{Nusikaltimus padariusiųjų asmenybės problematika šiuolaikinèje kriminologijoje}

Kriminologinèje literatūroje vyksta diskusija dèl nusikalstamą veiką padariusio asmens asmenybės sampratos, turinio ir apskritai tokio termino vartojimo tikslingu$\mathrm{mo}^{19}$. Straipsnyje trumpai pateikiama nusikaltèlio asmenybès samprata ir daugiausia dèmesio skiriama nusikaltèlio asmenybès socialinių bruožų analizei, tyrimą koncentruojant ị recidyvisto asmenybės elementus, nes būtent recidyvisto asmenybè pasižymi išskirtiniais antisocialiniais bruožais.

Lietuvos Respublikos baudžiamojo kodekso 27 straipsnyje, be kiekybinių (formalių) recidyvo požymių, yra nustatyta, kad teismas, priimdamas apkaltinamąji nuosprendị už paskutinị nusikaltimą, atsižvelgęs ị kaltininko asmenybę, nusikalstamų ketinimų ịvykdymo laipsnị, ị dalyvavimo darant nusikaltimus pobūdị ir kitas bylos aplinkybes, asmeni gali pripažinti pavojingu recidyvistu ${ }^{20}$. Pakartotinai nusikaltusių asmenų elgesio charakteristikų išryškinimas padeda išsiaiškinti, kas paskatino asmenį nusikalsti, ar paskirta bausmė už pirminị nusikaltimą buvo efektyvi, ar ją atlikus nuteistojo resocializacija buvo veiksminga, ką reikia daryti siekiant išvengti pakartotinių nusikaltimų, - tai padeda nustatyti pagrindines pakartotinio nusikalstamumo prevencijos kryptis.

Kriminologijos mokslas yra sukaupęs nemažai žinių apie nusikaltimą padariusiojo asmenybę. Ją, be kriminologijos, jau daugelį metų nagrinejja psichologija, sociologija, antropologija bei kiti mokslai. Kriminologiniai tyrimai, nukreipti ị bet kurią nusikalstamumo rūšĭ, visuomet pasiremia ir nusikaltèlio asmenybès analize. Pvz., recidyvisto asmenybè yra vienas iš pavojingiausių socialinių asmenybės tipų, kadangi pats recidyvinis nusikalstamumas yra vienas iš negatyviausių ir pavojingiausių socialinių reiškinių, todèl kriminologiniuose tyrimuose šiai problemai skiriama daug dèmesio.

19 Babachinaitè, G.; Galinaitytè, J.; Jurgelaitienè, G. et al. Kriminologija: vadovèlis. Moks. red. Babachinaite, G.; Kiškis; A. Vilnius: Mykolo Romerio universiteto Leidybos centras, 2010, p. 243-248.

20 Lietuvos Respublikos baudžiamasis kodeksas. Valstybės žinios. 2000, Nr. 89-2741 (aktuali redakcija). 
Recidyvistas - tai nebe pirmąkart nusikaltimą padaręs asmuo, turintis tam tikrų specifinių bruožų, igūdžių ir ịpročių, skiriančių jị nuo asmens, nusikaltusio pirmą kartą. Recidyvisto asmenybe - tai stipriai išreikštų antivisuomeninio elgesio charakteristikų sudètingo formavimosi proceso rezultatas. Recidyvisto asmenybė susiformuoja palaipsniui, veikiama ịvairių veiksnių, išorinès ir vidinès aplinkos sąlygų; jai yra būdinga negatyvių socialinių, psichologinių bei teisinių orientacijų visuma. Tai teisine prasme antivisuomeninè (nesocializuota) asmenybè. Nusikaltèlio recidyvisto asmenybė - tai visuma tarpusavyje susijusių socialiai reikšmingų neigiamų savybių ir santykių, kurie sąveikaudami su išorinėmis sąlygomis ir aplinkybėmis nulemia pakartotinių nusikalstamų veikų padarymą.

Baudžiamosios atsakomybės už pakartotinių nusikaltimų padarymą masto didinimas iš esmès remiasi recidyvisto asmenybès socialinio pavojingumo koncepcija, kuri teigia, kad nusikaltimą padaręs asmuo (lyginant su niekuomet nenusikaltusiu asmeniu) turi negatyvių, pavojingų visuomenei bruožų, savybių, požiūrių, orientacijų ir net poreikių.

Kita vertus, kasdieniniame gyvenime mes sutinkame nusikalstamas veikas padariusius asmenis ir matome, kad daugumos iš jų mąstymas bei elgesys beveik niekuo nesiskiria nuo kitų, nenusikaltusių žmonių. Žmogus yra sudètinga būtybè, ir nẻ vienas nèra apsaugotas nuo galimybès nusikalsti.

Teoriškai galima išskirti recidyvisto asmenybės charakteristikų, lemiančių nusikalstamą elgesí, sistemą. Pagrindiniai jos elementai: 1) motyvai ir poreikiai; 2) moralè ir teisinè sąmoné; 3) socialinès pozicijos ir ryšiai; 4) socialiai reikšminga veikla.

Motyvai ir poreikiai. Nusikaltèlių recidyvistų elgesio motyvų sistema yra žymiai siauresnè nei pirmą kartą nusikaltusių arba niekuomet nenusikaltusių asmenų elgesio motyvų sistema. Recidyvisto asmenybès formavimosi procese atsiranda nauji primityvūs elgesio motyvai bei keičiasi motyvų sistemos hierarchinė struktūra. Šioje hierarchijoje ima dominuoti egoistiniai, materialiniai, vartotojiški, trumpalaikiai poreikiai ir motyvai. Todèl dauguma recidyvistų yra absoliučiai nemotyvuoti turèti nuolatinị darbą. Ilgalaikis nedarbas reiškia lèšų pragyvenimui trūkumą, o tai yra glaudžiai susiję su neišvengiama nusikalstamos karjeros tąsa. Su ilgalaikiu nedarbu taip pat yra susijusi ir asmens poreikių deformacija, kuri reiškia materialinių interesų iškèlimą virš dvasinių (bendravimo, kūrybos, mokymosi poreikių), todèl dažniausiais pakartotinių nusikaltimų motyvais tampa savanaudiškumas, chuliganizmas, kerštas, pavydas, pyktis ir pan.

Moralés ir teisinés sąmonès charakteristika. Moralè, kaip ir teisé, visiems konkrečios visuomenės žmonèms kelia tam tikrus reikalavimus, kurie formuluojami kaip normos ir principai. Recidyvisto asmenybės moralės defektus pirmiausiai išryškina jo individualizmas. Recidyvistas visuomenèje dominuojančias moralès normas ir principus pakeičia žemomis individualiomis moralinėmis vertybėmis. Egzistuoja ryšys tarp asmenybès tapimo antivisuomenine, nepalankios socialinės aplinkos ir negatyvių asmenybès individualių savybių. Recidyvisto asmenybei yra būdingos tokios in- 
dividualios savybės kaip puikybė, gobšumas, egoizmas, žiaurumas, pavydas, kerštas, nejautrumas kitų nelaimèms, agresyvumas, nekantrumas, impulsyvumas, emocinių reakcijų neadekvatumas ir primityvumas, nesugebejjimas atidèti pasitenkinimo, naujų ịspūdžių siekimas ir pan. Toks asmuo gali pavogti todèl, kad tuo momentu neturi su savimi pinigu ar tiesiog nenori vargintis mėgindamas jų gauti teisètai; nuo antivisuomeninių veiksmų jo negali sulaikyti ir bausmès grèsmé; toks impulsyvumas, tenkinant poreikius, skatina asmenį iškilus kokioms nors kliūtims reaguoti agresyvumo protrūkiais ${ }^{21}$. Be išvardintų recidyvisto asmenybès individualių savybių, reikia paminèti, kad recidyvistams yra būdingas nesavikritiškumas, visiškas savo elgesio pateisinimas, ịtikèjimas nebaudžiamumu ir savo sẻkme, ciniškas požiūris ị svetimą nuosavybę, savo egoistinių poreikių išaukštinimas. Dauguma recidyvistų absoliučiai tiki savo veiksmų teisingumu, o jų nusikalstamos veikos demaskavimą laiko tik atsitiktinumu. Paprastai jie savo nusikalstamą elgeș̨ laiko atsaku ị nukentėjusiojo veiksmus, tokiu būdu pervertindami pačių susikurtą teisès pažeidimo motyvą ir besąlygiškai tikèdami nebaudžiamumu.

Kalbant apie recidyvisto asmenybę reikia paminèti ir kai kurias emocines, psichologines bei psichikos patologijas, būdingas recidyvistams. V. Kučinskas ir R. Kučinskienė nurodo, kad nusikaltimai yra negatyvių veiksnių komplekso padariniai, kuriuos nulemia ištisa virtinè ankstesnių negatyvių ivykių, visuomeninių ir asmeninių veiksnių santykis. Vienas iš negatyvių veiksnių yra emociniai sutrikimai, kuriuos sukelia ịvairūs charakterio sutrikimai. Paminètini tokie charakterio sutrikimai, kaip depersonalizacija (žmogaus standartizacija, individualybès praradimas, bet kokios prasmès veikti praradimas), depresija (prislègtų jausmų būsena, minčių slopinimas, neigiamos emocijos, mažas darbingumas, mintys apie savižudybę), bejègiškumas (išorinių poveikių sureikšminimas, nuolatinè stresinè būsena), kliedèjimas (nepasitenkinimas savo kūno struktūra, fizine išvaizda, laikysena), filosofinès intoksikacijos sindromas (nepagrịstas mėginimas pertvarkyti pasaulị, lengva šizofrenija), fobija (stiprus nenoras mokytis, mokyklos baimé, liguistas fizinio darbo vengimas) ${ }^{22}$. Apie 15-20 proc. recidyvistų yra diagnozuojamos psichikos patologijos (nereiškiančios neveiksnumo), o nužudymus padariusių recidyvistų - net 40 proc. Tačiau demonstratyvi neurastenija bei elgesio sutrikimai daugeliui jų yra atsiradę dèl savo gyvenimo ir likimo nuvertinimo, savikontrolès nebuvimo.

Recidyvistų nusikalstamą elgesị suponuoja ne tik iškreipta jų moralès normų ir principų sistema, bet ir pozityviai egzistuojančių teisès normų nuvertinimas bei baudžiamosios atsakomybės grèsmès ignoravimas. Recidyvistai paprastai labai gerai žino baudžiamojo ịstatymo turinị ir net Baudžiamojo kodekso straipsnius, tačiau šis jų žinojimas yra labai siauras ir formalus, jie nesuvokia teisės principų ir jų socialinès

21 Kočiūnas, R. Psichologinis konsultavimas. Vilnius: Lumen, 1995, p.149.

22 Kučinskas, V.; Kučinskienè, R. Socialinis darbas švietimo sistemoje: teoriniai aspektai. Klaipèda: Klaipèdos universiteto leidykla, 2000. p. 159-160. 
reikšmės. Recidyvistų teisinė sąmonė yra nesusiformavusi, prieštaringa; jų sąmonė aktyviai priešinasi teisinių draudimų suvokimui ir prièmimui. Akivaizdžiai recidyvisto teisinès sąmonès deformacijos laipsnị parodo tai, kaip recidyvistas vertina teismo nuosprendžio ir jam paskirtos bausmès teisingumą. Daugeliu atvejų yra stebima atvirkštiné teistumų skaičiaus ir pozityvaus bausmès teisingumo vertinimo priklausomybè: kuo daugiau recidyvistas turi teistumų, tuo rečiau jis mano, kad jam paskirta bausmè buvo teisinga ir adekvati padarytam nusikaltimui.

Socialinés pozicijos ir ryšiai. Nors žmogus ir gimsta su genetiškai užprogramuotais temperamento bruožais, tačiau deviantinio (nusikalstamo) elgesio yra išmokstama gyvenant visuomenèje. Pagal G. Valicko apibūdintą diferencinès asociacijos teoriją, „nusikalstamas elgesys iggyjamas tada, kai žmogus susiduria su nepageidautino elgesio pavyzdžiais ir kartu yra izoliuojamas nuo prosocialaus elgesio šaltinių “23. Nusikalstamo elgesio asmenybe išmoksta bendravimo proceso metu. Didžiausią poveikị šiam išmokimui turi artimiausia aplinka - šeima, mokykla, bendraamžių grupés; nemažai ịtakos turi ir visuomenės informavimo priemonès. Taigi, veikiant visiems šiems veiksniams, o tuo labiau - asmenybei turint nepageidaujamų individualių savybių, tiketina, kad nusikalstamas elgesys bus išmoktas. Jeigu artimiausioje asmenybès aplinkoje prosocialios vertybės yra ignoruojamos, o antivisuomeninès laikomos priimtinomis ir dar pastiprinamos (paskatinamos, apdovanojamos), susidarys palankiausios sąlygos asmenybès desocializacijai.

Recidyvistai paprastai daugiausiai bendrauja „savame rate“, kadangi tik čia jie suranda bendraminčius, suprantančius jų poreikius ir siekius. Taigi, recidyvistui nuolat bendraujant su kitais asmenimis, kuriems itin būdingos antivisuomeninès nuostatos, bendravimą paįvairinant alkoholiu bei narkotikais, susiformuoja tam tikri socialiniai antivisuomeniniai ryšiai bei antivisuomeninès asmenybės pozicijos.

Analizuojant recidyvistų asmenybę, pastebimos ir jų šeiminių santykių socialinių pozicijų deformacijos. Pasak V. Justickio, kriminologiniai tyrimai patvirtino tai, kad žmonės, kurie daug kartų padaro nusikaltimus, daugeliu bruožų išsiskiria iš kitų žmonių; pirmiausia, „jie iš tikrųjų turèjo blogą šeimą “24. Daugumos recidyvistų tèvai buvo išsiskyrę arba nuolat konfliktuodavo, šeimoje nebuvo šiltų santykių, vaikai nebuvo mylimi; kuris nors iš šeimos narių buvo teistas. Be to, reikia paminèti ir žemą šeimos, kurioje recidyvistas užaugo, socialinị statusą, tai yra mažas šeimos pajamas ir blogas, vargingas gyvenimo sąlygas. Suaugę recidyvistai paprastai arba iš viso neturi jokių šeiminių ryšių, arba šie ryšiai yra iširę, juos pakeičia atsitiktiniai santykiai. Recidyvistai dažnai keičia gyvenamąją vietą. Jų santykiai su kitais šeimos nariais yra primityvūs; jie sukuria šeimas tik su panašiais ị save asmenimis. Recidyvistai dažnai neigia savo tèvystę, vengia išlaikyti nepilnamečius vaikus bei senyvus tẻvus. 
Dauguma recidyvistų pirmą kartą nusikalsta būdami nepilnamečiai arba pirmaisiais pilnametystės metais. Kriminologiniais tyrimais yra nustatyta tiesioginè priklausomybė tarp nusikalstamos karjeros pradžios ir tolesnio nusikaltimų recidyvo: kuo anksčiau nepilnamečiai nusikalsta, tuo paskesnis jų recidyvas yra intensyvesnis ir pavojingesnis; pirmą kartą nusikaltus sulaukus pilnametystès, recidyvo tikimybė žymiai sumažèja, o senyvame amžiuje beveik niekas nepradeda recidyvinès biografijos $^{25}$. Vidutinis recidyvistų amžius yra šiek tiek didesnis nei pirmą kartą nusikaltusių asmenų, tačiau paskutiniu metu šis amžiaus skirtumas palengva mažèja. Bendra nusikalstamumo jaunejjimo tendencija tinka ir recidyviniam nusikalstamumui. Dauguma recidyvistų yra nuo 21 iki 30 metų amžiaus; tai palyginti jaunas amžius, turint omenyje tai, kad šie asmenys nusikalto nebe pirmą kartą.

Apžvelgiant socialinius demografinius recidyvisto požymius, reikia pasakyti, kad recidyvinis nusikalstamumas yra būdingesnis vyriškajai visuomenès daliai. Recidyvisčių moterų yra užregistruota apie 2-3 kartus mažiau nei pirmą kartą nusikaltusių moterų, o bendroje nusikalstamumo statistikoje matyti, jog moterys 6-7 kartus rečiau nusikalsta nei vyrai. Beje, reikia pažymèti, kad moterų recidyvisčių kriminogeninès savybės yra negatyvesnès nei vyrų, kas pasireiškia labiau paplitusiu alkoholizmu, didesniu teistumų skaičiumi, socialinių ryšių nutrūkimu, benamyste, moraline degradacija. Šių reiškinių priežastis yra ta, kad moteris visuomet sunkiau pergyvena šeimos iširimą nei vyrai, kurie dažniau ir greičiau išsiskiria su nuteistomis žmonomis, nei moterys - su nuteistais vyrais. Psichologinès bei fiziologinès moterų savybès nulemia tai, kad jos greičiau tampa alkoholikèmis ir narkomanèmis. Be to, visuomenès nuomonè yra žymiai griežtesnè teistoms moterims nei vyrams, dèl ko moteris recidyvistes neretai atstumia draugai, jos nesulaukia geranoriškumo ir žmogiško bendravimo.

Kaip buvo minèta, dauguma recidyvistų pirmą kartą nusikalsta būdami nepilnamečiai arba jauno amžiaus. Dèl anksti prasidejusios kriminalinės karjeros recidyvistų išsilavinimo lygis yra žymiai mažesnis nei kitų asmenų, jų darbinė kvalifikacija yra labai menka arba jie neturi jokios kvalifikacijos, neturi darbo stažo.

Kriminologijos literatūroje yra nemažai kalbama apie laisvès atėmimo bausmès itaką recidyvisto asmenybès formavimuisi. Prof. J. Bluvšteinas nurodo, kad laisvès atėmimo paradoksalumas pasireiškia tuo, kad ši bausmė orientuota į nuteistojo resocializaciją, t. y. turi atkurti sugebejimą gyventi visuomeneje, bet kartu ilgą laiką izoliuoja jị nuo visuomenès ${ }^{26}$. Daugelio nuteistųjų sąmonėje laisvès atėmimo bausmès atlikimas suformuoja ipročius dirbti ir vykdyti kitas pareigas tik veikiant sankcijų baimei, todèl išèję ị laisvę tokie asmenys jaučiasi išsilaisvinę iš prievartinio darbo ir socialinių pareigų vykdymo. Suprantama, kad šis „laisvès“ pojūtis neskatina jų nei dirbti, nei prosocialiai elgtis visuomeneje. Be to, nuteistieji asmenys laisvès atèmimo 
vietose ịgyja ir kitų ịpročių - būti kartu su kitais, panašiais ị juos. Ypač tie nuteistieji, kurie yra praradę socialinius ryšius, išèję ị laisvę jaučia stiprų poreikị bendrauti su kitais laisvès atėmimo bausmę atlikusiais asmenimis. Laisvès atėmimo vietose nuteistųjų asmenybei dideli poveikị turi ne tik valstybès organizuojama kontrolè ir jos poveikio priemonès, bet ir kriminalinè subkultūra ${ }^{27}$.

Tebesantis neformalus nuteistųjų susiskirstymas $\mathfrak{i}$ atskiras kategorijas Lietuvos pataisos įstaigose skatina vienų kategorijų nuteistụjų prievartą kitų kategorijų atžvilgiu, padeda igyti neigiamos kriminalinès patirties bei aukštesnę kriminalinę kvalifikaciją, užmegzti naujus socialinius tarpusavio santykius, sustiprina kriminalines ir apskritai antisocialines nuostatas. Minèti veiksniai ir pataisos ịstaigose nuteistųjų susiformuoti ịpročiai padidina riziką, kad ị laisvę išẻjęs recidyvistas, susidūręs su gyvenimo sunkumais ar kriminogenine situacija, pasirinks kriminalinę aplinką ir neteisètus tikslų siekimo būdus.

\section{Išvados}

Nusikalstamumas yra dinamiškas socialinis teisinis reiškinys, tiesiogiai susijęs su visais valstybeje vykstančiais procesais, pasižymintis permanentiškumu. Dèl to nusikalstamumo arba atskirų jo elementų stabilizavimasis arba netgi mažejimas savaime nepanaikina nusikalstamumo prevencijos problemų. Kriminologinè problematika yra permanentiškai aktuali, gali keistis tik aktualumo kryptingumas, t. y. gali būti išskiriami tam tikri jo akcentai. Nusikalstamumo prevencijos pagrindą turi sudaryti strateginio pobūdžio principai, užtikrinantys veiklos tęstinumą, šio reiškinio tyrimų tarpdiscipliniškumą ir nuolatinę stebėseną.

Ilgalaike kriminologinių tyrimų praktika rodo, kad registruoto nusikalstamumo lygis ne visuomet atspindi tikrąją kriminogeninę situaciją valstybejje. Registruoto nusikalstamumo dinamika gali priklausyti ne tik ir ne tiek nuo visuomenejje vykstančių procesų ir realiai padaromų nusikalstamų veikų skaičiaus, kiek nuo politinės valios, nusikalstamų veikų registravimo tvarkos pokyčiu ir t. t. Tad objektyvesniam kriminogeninès situacijos vertinimui svarbus visapusiškas kriminologinès statistikos kūrimo išmanymas bei specifinės žinios.

Viktimologinis aspektas kriminologijoje yra svarbus ne tik siekiant suvokti asmenims nusikalstamomis veikomis daromos žalos mastą, pobūdị, bet ir visapusiškai vertinant galimą viktimizaciją asmenų, kurie baudžiamajame procese niekada nebus pripažinti nukentejusiaisiais (pasikèsinimų papirkti ir kitais atvejais).

Nusikaltèlio recidyvisto asmenybe - tai visuma tarpusavyje susijusių socialiai reikšmingų neigiamų savybių ir santykių, kurie sąveikaudami su išorinėmis sąlygomis ir aplinkybėmis nulemia pakartotinių nusikalstamų veikų padarymą. Ši samprata 
tampa aktuali ịveikiant anksčiau naudotą ir iš esmès save diskreditavusią „nusikaltèlio asmenybès" sampratą, kurios turinys, kaip parodè praktika, dažnai niekuo nesiskirdavo nuo teisei lojalaus asmens asmenybès turinio.

\section{Literatūra}

Babachinaitè, G. Kriminalinès viktimizacijos Lietuvoje pagrindinių statistinių rodiklių kriminologinè analizè. Jurisprudencija. 2011, 18(3).

Babachinaitè, G.; Galinaitytè, J.; Jurgelaitienè, G., et al. Kriminologija: vadovelis. Moks. red. Babachinaite, G.; Kiškis, A. Vilnius: Mykolo Romerio universiteto Leidybos centras, 2010.

Babachinaite, G. Kriminologiniai nusikalstamumo raidos Lietuvoje periodizacijos aspektai. Lietuvos teisés tradicijos: mokslinès konferencijos medžiaga. Vilnius: Justitia, 1997.

Babachinaitè, G. Saugumo jausmo ir nusikaltimų baimès raida Lietuvoje. Jurisprudencija. 2006, 1(79).

Babachinaitè, G. Šiuolaikinio registruoto nusikalstamumo Lietuvoje pagrindiniai bruožai. Jurisprudencija. 2012, 19(4).

Babachinaitè, G. Viešoji nuomonè ir mirties bausmè: prevencijos strategija. Jurisprudencija. 1998, 10(2).

Chistie, N. Limits to pain. Oxford, Martin Robertson, 1992.

Christie, N. Crime control as Industry. London, New York, 1993.

Fedosiuk, O. Baudžiamoji atsakomybe kaip kraštutinė priemonè (ultima ratio): teorija ir realybė. Jurisprudencija. 2012, 19(2).

Gavėnaitè, A. Bausmès samprata ir funkcijos pozityvistineje ir kritineje kriminologijos tradicijose. Daktaro diserta- cija. Socialiniai mokslai, sociologija. Vilnius: Vilniaus universitetas, 2008, Justickis, V. Kriminologija. I dalis. Vilnius: Lietuvos teisès universitetas, 2001.

Kalejimų departamentas prie Teisingumo ministerijos. Asmenų, laikomų KD įstaigose, skaičius metų pradžioje [interaktyvus]. [žiūrèta 2013-09-10]. <http://www.nplc.lt:8000/asis/>.

Kalejimų departamento prie Lietuvos Respublikos teisingumo ministerijos 2012 metų veiklos ataskaita. 2013, Nr. 1S-440 [interaktyvus]. [žiūrèta 201309-23]. <http://www.kalejimudepartamentas.lt/lt/kalejimu-departamentas/veikla/ataskaitos/metines.html>.

Kočiūnas, R. Psichologinis konsultavimas. Vilnius: Lumen, 1995.

Kriminologija. Atsakingasis redaktorius Bluvšteinas, J. Vilnius: Pradai, 1994.

Kriminologija: uchebnik [Criminology: Handbook]. Pod red. Kuznecovoj, N. F.; Lunejeva, V. V. Moskva, 2005.

Kučinskas, V.; Kučinskiene, R. Socialinis darbas švietimo sistemoje: teoriniai aspektai. Klaipèda: Klaipėdos universiteto leidykla, 2000.

Lietuvos Respublikos baudžiamasis kodeksas. Valstybès žinios. 2000, Nr. 892741 (aktuali redakcija).

Lietuvos Respublikos baudžiamojo kodekso 22, 24, 42, 43, 49, 50, 54(1), 71, $75,105,227^{(1)}, 227^{(3)}$ straipsnių pakei- 
timo įstatymas. Valstybès žinios. 1998, Nr. 115-3238.

Lietuvos Respublikos Vyriausybès 2012 m. lapkričio 14 d. nutarimas $\mathrm{Nr} .1381$ „Dèl nacionalinès nusikaltimų prevencijos ir kontrolès programos igyvendinimo tarpinstitucinio veiklos plano patvirtinimo“. Valstybès žinios. 2012, Nr. 135-6897.

Petkus, A. Kriminalinè subkultūra ir jos itaka recidyviniam nusikalstamumui. Jurisprudencija. 2001, 20(12).

Povilaitis, Br. Lietuvos žemès ūkis 1918-1940. Vilnius: Tèvynès sargas, 1997.

Tyčiniai nužudymai (su pasikèsinimais) [interaktyvus]. [žiūrèta 2013-08-29]. <http://www.nplc.lt/sena/stat/nus/ nus11.htm>; Duomenys apie nusikalstamumą Lietuvos Respublikoje. Užregistruotos ir ištirtos nusikalstamos veikos (Forma 1 Ž). Informatikos ir ryšių departamentas prie Vidaus reikalų ministerijos [interaktyvus]. [žiūrèta 2013-08-29]. <http://www. nplc.lt:8000/asis/>.

Valickas, G. Psichologines asocialaus elgesio ištakos. Vilnius: Lietuvos teisès akademija, 1997.

Vileikienè, E. Lietuvos gyventojų požiūris ị teismus [interaktyvus]. [žiūrèta 201403-07]. <http://www.teismai.lt/dokumentai/gyventoju\%20apklausa $\% 20$ \%28teismai\%29\%202013.pdf>.

Anotacija. Straipsnyje nagrinejjama kriminogeniniu procesu dinamika dèsningu bei neprognozuojamu socialinių, ekonominių, politinių pokyčiu fone, ieškoma metodologinio pagrindo kriminogeniniu faktoriu prognozavimui tobulinti. Analizuojamos aktualios nusikalstamumo prevencijos problemos, nusikalstamumo raidos rodikliai Lietuvoje, kriminalinès viktimizacijos pagrindiniai rodikliai, nusikaltimu baimès raida Lietuvoje, kriminologijai svarbūs nusikalstamą veiką padariusiojo asmenybès bruožai.

Reikšminiai žodžiai: nusikaltimai, baudžiamieji nusižengimai, nusikalstamumo prevencija, kriminalinè viktimizacija, nusikalstamumo raida, socialiniai pokyčiai.

\title{
SOME ESSENTIAL CRIMINOLOGICAL PROBLEMS IN THE CONTEXT OF THE SOCIAL CHANGES IN LITHUANIA DURING THE LAST TWENTY YEARS
}

\author{
Genovaitė Babachinaitè, Artūras Petkus \\ Mykolas Romeris University, Lithuania
}

Summary. In this article, the context of crime in many aspects is analysed. A historical overview of statistical data analysis, victimisation processes, characteristics of victim and criminal personality and criminogenic process insights are presented 
in order to create conditions for further interdisciplinary research. It is emphasized that society supports and even requires an enhancement of democratic development in the processing of many fields of social and economic life, but the only "effective" tool they see in crime reduction is strengthening of penalties, derogation from offenders' rights and freedoms and many other restrictions. In fact, this opinion contravenes to numerous criminological surveys that proved success of pro-active prevention, in which the community takes the key role, and disproved effectiveness of harsh, but erratic penal policy of the state. Thus, the importance of law enforcement institutions in crime reduction activities is specified and identified as minor.

Crime rates for the last century are also analysed in this article. It is noticed that the state criminological data may vary subject to political will of the state authorities or crime recording rules. Crime rates assessment must be based on clear information about all those conditions.

It is emphasized that temporal levelling-off in crime rates or even temporal reduction in crime rates does not reduce criminological issues in the whole. Crime as a negative social-legal phenomenon is widely connected with all social phenomena, such as economy, employment, education, social relations, etc. So, it cannot be cancelled or defeated as simple as some of politicians like to present it. Criminological problems are permanent; they require constant solutions and systematic approach. Furthermore, the victimological aspect in criminology is also essential not only for a clear understanding of the scope and nature of the crime damage, but also for adequate assessing of potential victimization of people, who will never be recognized as victims in the criminal process (e.g., attempts to bribe and other cases).

In the authors' view, the concept of a personality of a criminal should be formulated more precisely to make a clear division between features of a law-loyal person and features of a criminal person. A criminal person is the whole of interdependent socially important negative features and relations interconnected with external conditions and factors, which determine repeated criminal activities. This concept is based on the general principle that personality changes only during some period of extremely negative criminal, anti-social experience, intentional criminal activities, when a person sustains social exclusion.

Genovaitė Babachinaitė, Mykolo Romerio universiteto Teisès fakulteto Baudžiamosios teisès ir proceso instituto profesoré. Mokslinių tyrimų kryptys: smurtinis nusikalstamumas ir jo prevencija, nepilnamečių teisès pažeidimų prevencija, teisinės sąmonės ir kriminalinės viktimizacijos problemos, nusikalstamumo Lietuvoje periodizacija.

Genovaitė Babachinaitė, Mykolas Romeris University, Faculty of Law, Institute of Criminal Law and Procedure, Professor. Research interests: violent crimes and their prevention, prevention of juvenile delinquency, problems of legal consciousness and criminal victimisation, periodisation of criminality in Lithuania. 
Artūras Petkus, Mykolo Romerio universiteto Teisès fakulteto Baudžiamosios teisès ir proceso instituto docentas. Mokslinių tyrimų kryptys: korupcijos tyrimai, priežastingumas, prevencija, korupcijos daroma žala, atskirų nusikalstamumo rūšių kriminologinė charakteristika, nusikaltèlio asmenybė, kriminalinè subkultūra.

Artūras Petkus, Mykolas Romeris University, Faculty of Law, Institute of Criminal Law and Procedure, Associate Professor. Research interests: corruption surveys, causation, prevention, damage of corruption, criminological characteristics of particular kinds of crimes, personality of criminal, criminal subculture. 